\title{
Alloying Effect of Silver on Zirconia Support Manipulated Palladium Catalyst for Methane Combustion
}

\author{
Mengmeng Chu, Fan Cai, Xiaohong Cao, Li Xing, Lefu Yang *, Xiaodong Yi and Weiping Fang \\ National Engineering Laboratory for Green Chemical Productions of Alcohols-Ethers-Esters, College of \\ Chemistry and Chemical Engineering, Xiamen University, Xiamen 361005, China; mmchu@139.com (M.C.); \\ caif@xmu.edu.cn (F.C.); cxhongcassie@126.com (X.C.); lixing13959265991@163.com (L.X.); \\ xdyi@xmu.edu.cn (X.Y.); wpfang@xmu.edu.cn (W.F.) \\ * Correspondence: lfyang@xmu.edu.cn
}

Received: 6 July 2020; Accepted: 28 July 2020; Published: 3 August 2020

\begin{abstract}
PdAg} / \mathrm{ZrO}$ alloy catalysts calcined at different temperatures were employed to elucidate the effect of support-metal interaction (SMI) on methane combustion. Combustion activity was depressed when the sample was calcined at an elevated temperature from $500{ }^{\circ} \mathrm{C}$ to $700{ }^{\circ} \mathrm{C}$. However, calcination at $850^{\circ} \mathrm{C}$ enhanced the beneficial SMI, which facilitated a more active phase for the oxidation reaction. The high-resolution transmission electron microscopy experiments show that a special micro-domain structure at the interface is formed during the reduction pretreatment. $\mathrm{H}_{2}-\mathrm{TPR}$ and $\mathrm{O}_{2}$-TPD measurements illustrate that the active phase would undergo reconstruction upon redox cycles. The active phase manipulated by the support is more suitable for combustion reaction in the course of temperature altering.
\end{abstract}

Keywords: alloy catalyst; support-metal interaction; PdAg alloy; micro-domain; methane combustion

\section{Introduction}

Prominent environmental problems, especially the greenhouse effect, are increasingly being caused by unburned methane [1-4] and large amounts of $\mathrm{CO}_{2}$ emissions [5]. Catalytic combustion is a promising technology that can convert methane into carbon dioxide at relatively low temperature and has been extensively studied in recent years. The supported Pd-based catalyst has excellent catalytic performance [6-9], but the Pd-based catalyst has many shortcomings, impoverished thermal stability [10-12], poor selectivity [13], needy resistance to sulfide poisoning [14], etc. However, alloy catalysts can solve these problems. Pd-Pt alloy catalysts have good high-temperature thermal stability $[15,16]$ and enhance the anti-poisoning performance [17], Pd-Ni alloy catalysts have an adjustable electronic structure showing higher power density and high stability [18], and Pd-Ag nanoalloy catalysts can increase selectivity [13] and exhibit excellent activity $[19,20]$; thus alloy catalysts are increasingly gaining value.

A number of transition metal oxides supported on oxide from Groups II A, III B, IV B, and V B exhibit strong SMI, as reported by Tauster et al. in 1978 [21]. Murata et al. [22] illustrated that structure and particle size of the Pd nanoparticles were influenced by the SMI. Using $\mathrm{H}_{2}$ and CO chemisorption on metal particles supported catalysts. O'Shea et al. [23] found that the SMI effect could be explained via electron transfer from the support to the metal (electronic factor), or by the formation of intermetallic phases after reduction at high temperatures. As a consequence, the SMI [21-25] plays a decisive role in the structure and dispersion of the active phase.

In this study, experimental evidence demonstrates a relationship between the above-mentioned phenomena through methane combustion, $\mathrm{H}_{2}$ temperature programmed reduction $\left(\mathrm{H}_{2}-\mathrm{TPR}\right)$, and $\mathrm{O}_{2}$ temperature programmed desorption $\left(\mathrm{O}_{2}-\mathrm{TPD}\right)$ measurements. For this purpose, $\mathrm{PdAg} / \mathrm{ZO}_{2}$ catalysts 
are employed, and the calcining temperature is used as the main experimental variable. It is expected that the obtained results can be applied as the fundamental foundation for the catalytic methane combustion process, especially for the SMI and structure of the active phase at low temperatures.

\section{Results and Discussion}

\subsection{Microstructure of Catalyst}

\subsubsection{X-ray Diffraction Analysis}

Figure 1 shows the $\mathrm{XRD}$ patterns of $\mathrm{Pd} / \mathrm{Z}$ and $\mathrm{PdAg} / \mathrm{Z}$ series alloy catalysts; the crystal structure of $\mathrm{ZrO}_{2}$ is in monoclinic phase (JCPDS 01-086-1451), and the sharp peaks at $2 \theta=24.5^{\circ}, 28.2^{\circ}$ and $31.6^{\circ}$ can be assigned to (110), (-111) and (111) planes, respectively. We see that the dominant plane of $\mathrm{ZrO}_{2}$ is the (-111) plane. After co-loading, the $\mathrm{Pd}$ and $\mathrm{Ag}, \mathrm{PdAg} / \mathrm{Z}$ series alloy catalysts prepared by wetness impregnation method exhibit the same crystal structure as that of $\mathrm{ZrO}_{2}$. Importantly, no diffraction peaks ascribed to any $\mathrm{Pd}$ and $\mathrm{Ag}$ species can be observed, indicating that the particle size of $\mathrm{Pd}$ or $\mathrm{Ag}$ is quite small. The reasons may be: (I) the loading amount metal is relatively low; (II) the SMI can promote the dispersion of $\mathrm{PdAg}$ on $\mathrm{ZrO}_{2}$ surface and restrain aggregation.

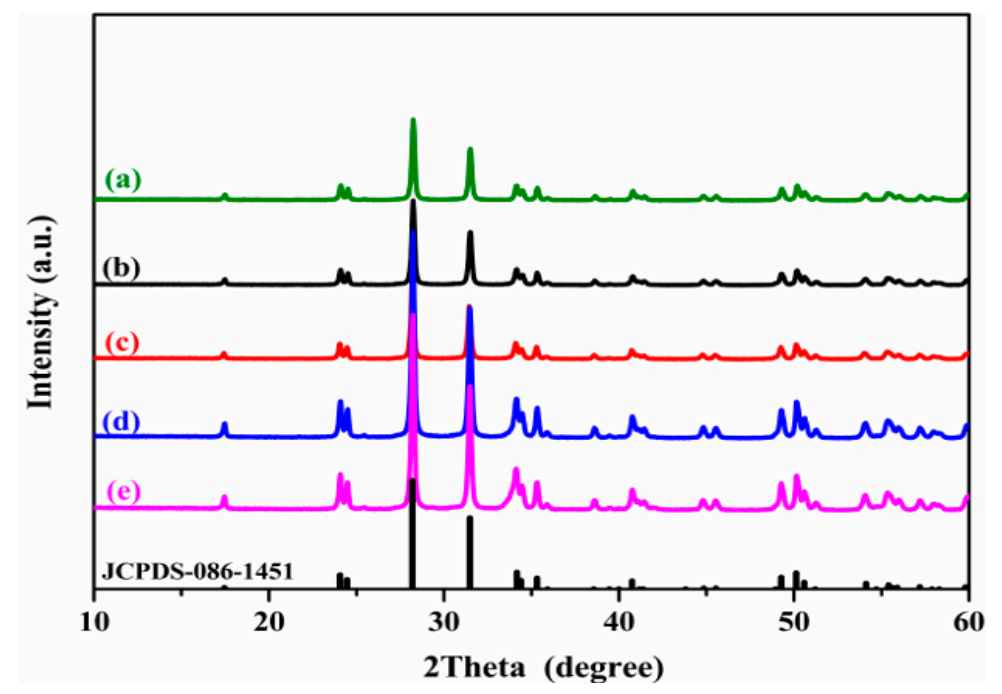

Figure 1. X-ray diffraction patterns of the support and catalysts: (a) $\mathrm{m}_{-} \mathrm{ZrO}_{2}$; (b) $1 \% \mathrm{Pd} / \mathrm{Z}$; (c) $1 \%$ $\mathrm{PdAg} / \mathrm{Z}$; (d) 2\% PdAg/Z; (e) 5\% PdAg/Z.

\subsubsection{High-Resolution Transmission Electron Microscopy Analysis}

Figure 2a,b show the HRTEM images of PdAg/Z-500, PdAg/Z-850 catalysts. It can be found that although the $\mathrm{PdAg}$ alloy particles become bigger after calcination at $850^{\circ} \mathrm{C}, \mathrm{PdAg}$ can still maintain dispersity, which is consistent with the fact that the PdAg alloy could enhance the thermal stability of $\mathrm{Pd} / \mathrm{Z}$ catalysts [20]. Figure 2c, d illustrate the HRTEM images of PdAg/Z-500 that was re-oxidized under air and re-reduced under $\mathrm{H}_{2}$ at $500{ }^{\circ} \mathrm{C}$. Clearly, the PdAg alloy particles are almost flat on the $\mathrm{ZrO}_{2}$ surface after re-oxidation. This phenomenon illustrates that the degree of SMI was strengthened after re-oxidation. Further, the SMI effect inhibits the growth of the metal particles at the interface between $\mathrm{PdAg}$ and the $\mathrm{ZrO}_{2}$ surface, thus forming a special micro-domain structure at the interface during the reduction process. By calculating the lattice fringes, we find that the SMI could manipulate the structure of the active phase. The fringe of the alloy particle $d=0.2296 \mathrm{~nm}$ is $\mathrm{Pd}$ (111) plane (PDF \# $87-0637, \mathrm{~d}=0.2301 \mathrm{~nm})$, for the fringe statistics with $\mathrm{d}=0.2700 \mathrm{~nm}$ at the micro-domain structure is $\mathrm{t}$-PdO (002) plane (PDF \# 43-1024, $\mathrm{d}=0.2668 \mathrm{~nm}$ ). Additionally, the $\mathrm{d}=0.3200 \mathrm{~nm}$ is ascribed to the $\mathrm{m}-\mathrm{ZrO}_{2}(-111)$ plane (PDF \# 86-1451, $\mathrm{d}=0.3164 \mathrm{~nm}$ ). Therefore, it can be concluded that the special micro-domain structure at the interface was a specific manifestation of SMI. 

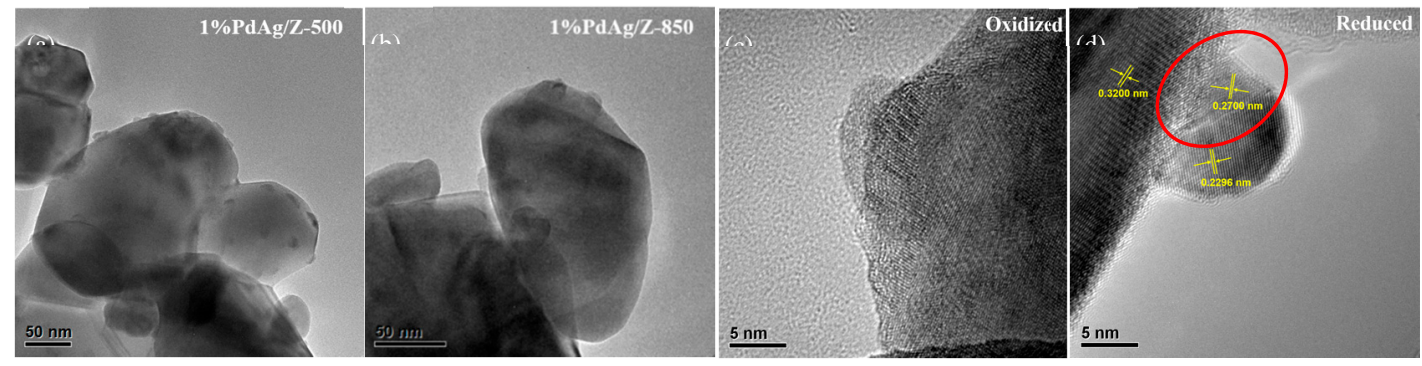

Figure 2. HRTEM images of supported alloy catalysts: (a) PdAg/Z-500; (b) PdAg/Z-850; (c) PdAg/Z-500 were re-oxidized under air at $500{ }^{\circ} \mathrm{C} ;(\mathbf{d}) \mathrm{H}_{2}$ re-reduced at $500{ }^{\circ} \mathrm{C}$.

Huang et al. [26] found that the ability of transforming Pd to PdO can show excellent performance for methane combustion. Besides, due to the good interaction between Pd and support, the mobility of active oxygen from support to $\mathrm{Pd}$ can readily achieve the goal of facilitating the stability of PdO species. In addition, Nilssona et al. [27] used XAFS characterization and found that the oxidation of Pd on the surface and bulk have a different impact on methane combustion. In the beginning of the reaction period, the surface of the catalyst is oxidized to form PdO. Following the reaction, the Pd oxidation state continues to increase, which corresponds to bulk oxidation of $\mathrm{Pd}$. This indicates that there is an interface between the surface PdO and bulk PdO. From Figure 2c,d, after re-oxidation, the catalyst is pure PdO. Due to the SMI, the interface is still PdO after re-reduction. Jiang et al. [28] reported that the bimetallic $\mathrm{Pt}-\mathrm{Pd} / \mathrm{ZrO}_{2}$ catalysts can maintain smaller nanoalloy particle size and narrow size distribution for alloy catalysts. As for PdAg/Z catalysts, due to the SMI, the metallic Pd and oxide PdO are reconstructed during the pretreatment, which makes the catalyst surface more enriched with PdO.

\subsection{Effect of Calcination Temperature}

\subsubsection{Catalytic Activity for Methane Oxidation}

To investigate the SMI effect on the catalytic performance, the PdAg/Z alloy catalysts prepared by different calcining temperature were evaluated by methane combustion. As shown in Figure 3 , $\mathrm{PdAg} / \mathrm{Z}-500$ ignites the oxidation reaction at $331^{\circ} \mathrm{C}\left(\mathrm{T}_{10}\right)$. After the ignition, the methane conversion increases rapidly with reaction temperature, and the burn-off is obtained at $443^{\circ} \mathrm{C}\left(\mathrm{T}_{90}\right)$. As expected, the calcination at higher temperature results in an obvious deactivation, which could be related to the sintering of active phase. The sample PdAg/Z-600 cannot ignite the oxidation until about $140{ }^{\circ} \mathrm{C}$ higher than PdAg/Z-500; even the burn-off still remains unachieved at $600^{\circ} \mathrm{C}$. However, further calcination at $700{ }^{\circ} \mathrm{C}$ brings about the recovery of catalytic activity and the light-off temperature over PdAg/Z-500 drops down to $423^{\circ} \mathrm{C}$. This implies that the construction towards a beneficial active phase occurs, much of it driven by the moderate SMI from the thermal treatment. The positive effect of SMI is proven to be enhanced after the supported alloy catalyst is calcined at $850{ }^{\circ} \mathrm{C}$. $\mathrm{PdAg} / \mathrm{Z}-850$ is able to ignite methane oxidation at $370{ }^{\circ} \mathrm{C}$.

Since the sintering at high temperature is usually irreversible, the recovery of catalytic activity cannot be attributed to the dispersion of active metal component. Because the methane oxidation promoted by noble metal catalysts typically has structural sensitivity, it will probably take advantage of active phase reassembly driven by SMI on the support template. This assumption has also been verified by an aging test over $\mathrm{PdAg} / \mathrm{Z}-850$, in which the active phase is optimized under reaction atmosphere. As shown in Figure 4, the catalyst was continuously tested at $350{ }^{\circ} \mathrm{C}$ for $50 \mathrm{~h}$. By holding the temperature at $350{ }^{\circ} \mathrm{C}$, the methane conversion gradually rose from 10 to $77 \%$ in the initial $6 \mathrm{~h}$ until a stable conversion of $80 \%$ was attained. In the whole period of $50 \mathrm{~h}$ aging test, no temporary or inclining decrease was observed. As the catalytic methane oxidation is composed by cyclic reduction and oxidation of the active phase, it offers the active phase an opportunity to reconstruct on the support template. The form of support template and interaction between the active phase and support would 
inevitably play a part in the reconstruction. The above experiments demonstrate that the zirconia support with monoclinic crystal phase and the epitaxy SMI are suitable for the improvement of active phase for catalytic methane combustion.

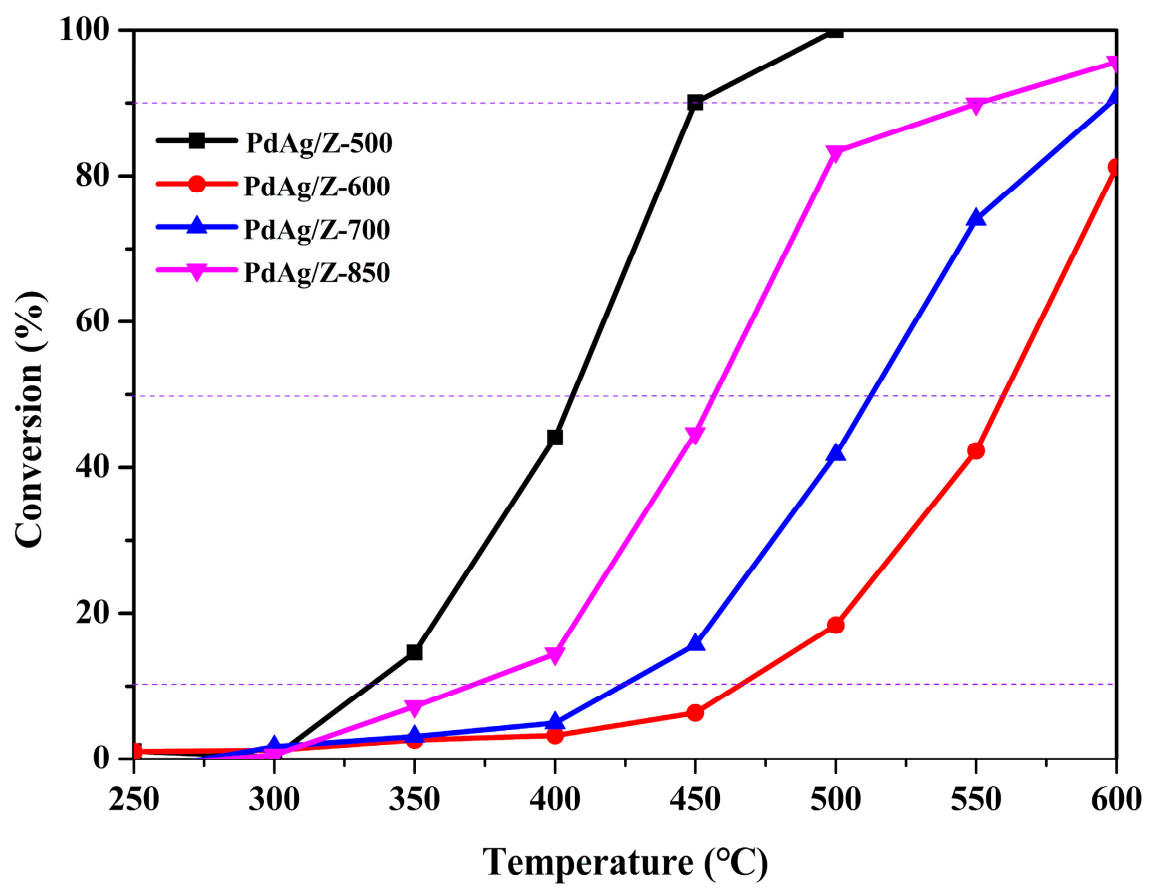

Figure 3. Methane conversion curve by $\mathrm{PdAg} / \mathrm{Z}$ alloy catalysts calcined at different temperatures. The reaction conditions were: heating rate $10{ }^{\circ} \mathrm{C} \mathrm{min}-1$ and flow rate of the reacting feedstock $40 \mathrm{~mL} \mathrm{~min}^{-1}$ (2 vol \% $\mathrm{CH}_{4} / \mathrm{Ar}$ and 4 vol \% $\mathrm{O}_{2} / \mathrm{Ar}$, space velocity $72,000 \mathrm{~h}^{-1}$ ).

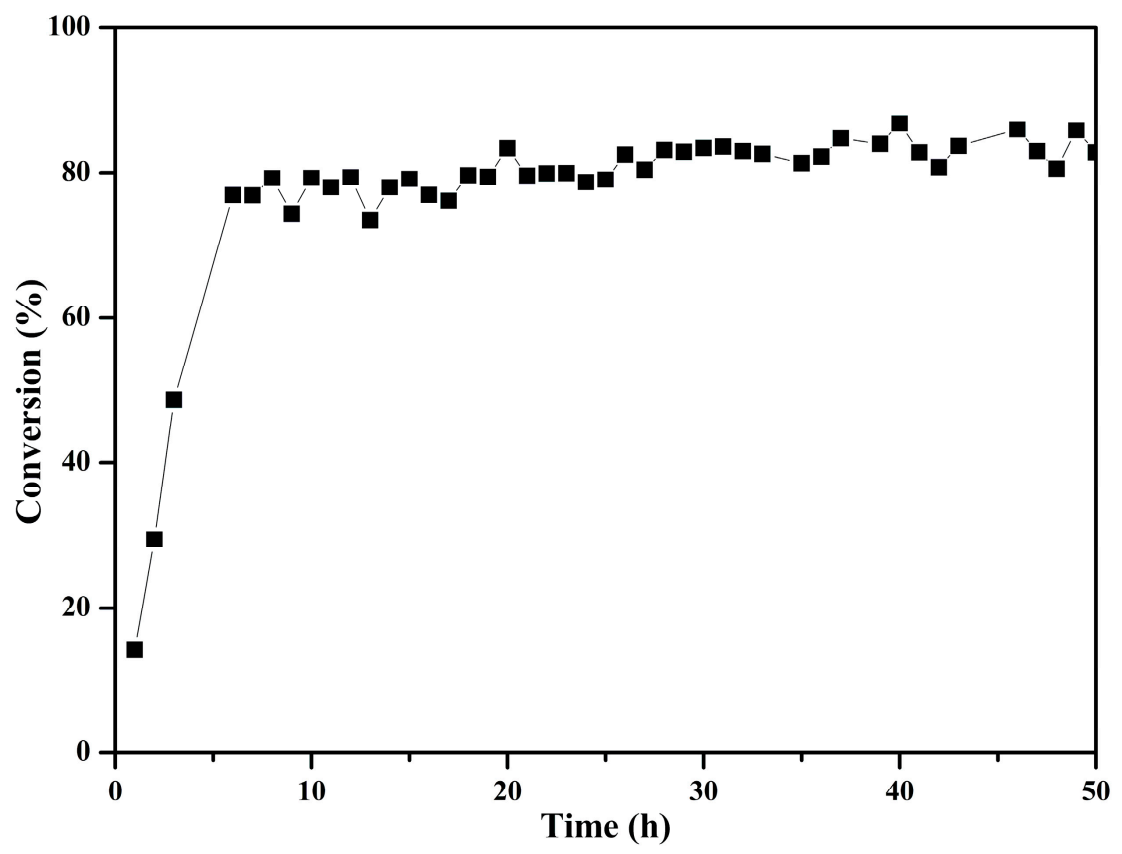

Figure 4. Methane conversion of the aging test for the $\mathrm{PdAg} / \mathrm{Z}-500$ catalyst at $350{ }^{\circ} \mathrm{C}$ for $50 \mathrm{~h}$. The feed gas consisting of $\mathrm{CH}_{4}: \mathrm{O}_{2}=1: 2, \mathrm{GHSV}=72,000 \mathrm{~h}^{-1}$. 


\subsection{2. $\mathrm{O}_{2}$ Temperature Programmed Desorption Analysis}

The catalytic activity is highly related to the active oxygen species; thus, the $\mathrm{O}_{2}$-TPD experiment was performed on the catalysts (Figure 5). The figure shows that $\mathrm{ZrO}_{2}$ does not have any $\mathrm{O}_{2}$ desorption signal, which means that all $\mathrm{O}_{2}$ desorption is caused by the decomposition of $\mathrm{Pd}$ and $\mathrm{Ag}$ oxides and the migration of $\mathrm{O}_{2}$ between the $\mathrm{PdAg}$ and $\mathrm{ZrO}_{2}$ interface [29]. When the calcination temperature is lower than $700{ }^{\circ} \mathrm{C}$, the desorption temperature of $\mathrm{O}_{2}$ gradually increases from $661.8^{\circ} \mathrm{C}$ to $698.2^{\circ} \mathrm{C}$ as the calcination temperature rises. However, when the calcination temperature is $850{ }^{\circ} \mathrm{C}$, the desorption temperature of $\mathrm{O}_{2}$ drops to $687.8^{\circ} \mathrm{C}$. This is because when the calcination temperature is lower than $700{ }^{\circ} \mathrm{C}$, the active phase sinters as the calcination temperature increases, strengthening the $\mathrm{Pd}-\mathrm{O}-\mathrm{Zr}$ structure and making the surface oxygen species more stable. However, when the temperature is up to $850^{\circ} \mathrm{C}$, it enhances the moderate SMI. It facilitates the active phase, which promotes active oxygen migration and reduces the desorption temperature of $\mathrm{O}_{2}$. Combining the catalytic activity and $\mathrm{O}_{2}-\mathrm{TPD}$ characterization, the catalytic activity is consistent with the change trend of $\mathrm{O}_{2}$ desorption temperature.

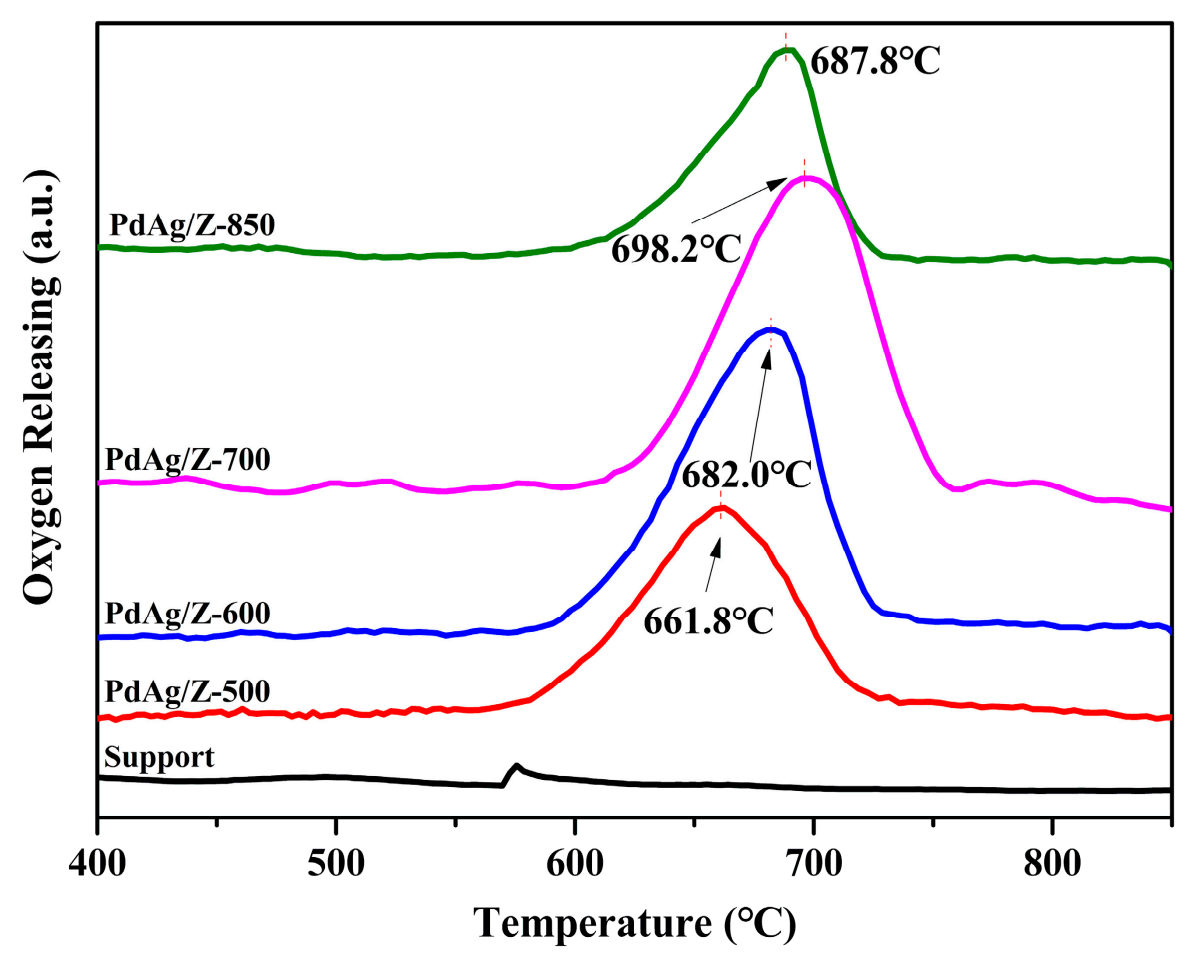

Figure 5. $\mathrm{O}_{2}$ temperature programmed desorption $\left(\mathrm{O}_{2}-\mathrm{TPD}\right)$ profiles of $\mathrm{PdAg} / \mathrm{Z}$ catalysts calcined at different temperatures.

To explore the reconstruction behavior of active oxygen during the reaction, the $\mathrm{O}_{2}$-TPD cycle desorption experiment was designed; the results are shown in Figure 6. After the oxygen desorption temperature was elevated to $700{ }^{\circ} \mathrm{C}$, it was immediately dropped to $200{ }^{\circ} \mathrm{C}$ and then increased again. When the temperature rises to $574^{\circ} \mathrm{C}$ again, $\mathrm{O}_{2}$ desorption occurs as before. This implies that by the cycling of temperature, $\mathrm{O}_{2}$ with desorption temperature higher than $700{ }^{\circ} \mathrm{C}$ will be reconstructed to low temperature for desorption. It is suggested that the manipulation of the $\mathrm{PdO}$ active phase by $\mathrm{m}-\mathrm{ZrO}_{2}$ template is more advantageous to the exchange of oxygen. 


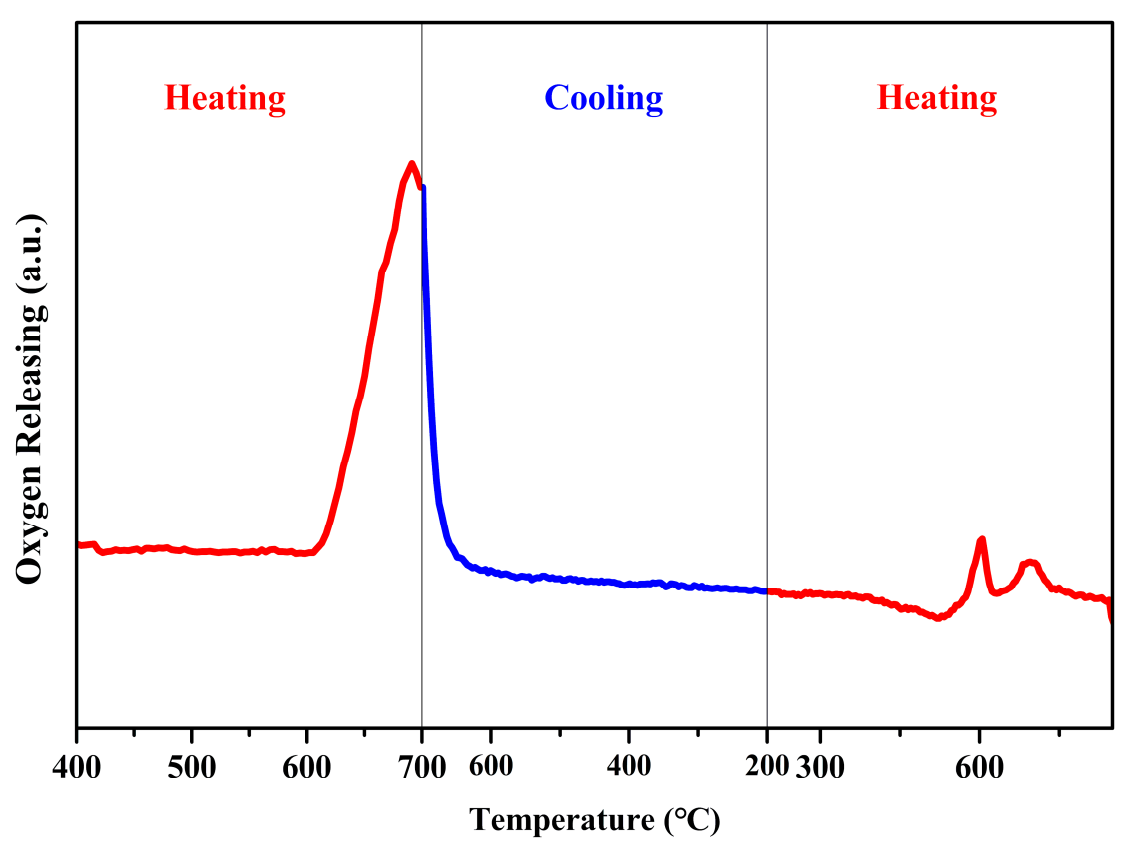

Figure 6. $\mathrm{O}_{2}$ temperature programmed desorption $\left(\mathrm{O}_{2}-\mathrm{TPD}\right)$ cyclic desorption profiles of the PdAg/Z500 catalyst.

\subsection{3. $\mathrm{H}_{2}$ Temperature Programmed Reduction Analysis}

Figure 7 shows the $\mathrm{H}_{2}$-TPR patterns of $\mathrm{PdAg} / \mathrm{Z}$ catalysts. In order to better observe the hydrogen consumption signal, the polarity of the detector was reversed during the $\mathrm{H}_{2}$-TPR experiment, such that the $\mathrm{H}_{2}$ consumption signal was converted into $\mathrm{H}_{2}$ desorption signal. The inner illustration is the detection limit of the detector. The $\mathrm{H}_{2}$-TPR profiles consist of three reduced peak, $\alpha, \beta$, and $\gamma . \alpha$ (about $50{ }^{\circ} \mathrm{C}$ ) is attributed to the reduction of surface $\mathrm{PdO}$ species and absorbed oxygen on the surface of catalyst [30]. $\beta\left(80-120{ }^{\circ} \mathrm{C}\right)$ is pertinent to the decomposition of $\mathrm{PdH}_{\mathrm{X}} \cdot \gamma\left(\mathrm{T} \max 250-350{ }^{\circ} \mathrm{C}\right)$ is assigned to the reduction of subsurface $\mathrm{PdO}$ on the catalyst surface [31]. The decomposition temperature of the peak reflects the SMI. The $\mathrm{PdAg} / \mathrm{Z}$ alloy catalyst calcined at $500{ }^{\circ} \mathrm{C}$ had the highest decomposition temperature of $\mathrm{PdH}_{X}$ at $81.7^{\circ} \mathrm{C}$, but with the increase of calcination temperature, $\mathrm{PdH}_{X}$ decomposition temperature is gradually reduced, that is because with the increase of calcination temperature, the degree of SMI is strengthened and free $\mathrm{Pd}$ on the catalyst surface is reduced, making $\mathrm{PdH}_{\mathrm{X}}$ to be too stable to decompose at lower temperatures.

\subsubsection{CO Temperature Programmed Reduction Analysis}

Compared with $\mathrm{H}_{2}$-TPR, CO-TPR can avoid the split of $\mathrm{H}_{2}$. Besides, the reduction of $\mathrm{CO}$ is weaker and the reduction slower than $\mathrm{H}_{2}$, so it can well express the relationship between the various oxide species. Figure 8 is the CO-TPR curve of a series of $\mathrm{PdAg} / \mathrm{Z}$ catalysts. As shown in Figure 8, the reduction of $\mathrm{PdAg} / \mathrm{Z}$ bimetal has mainly three peaks. For the $\mathrm{ZrO}_{2}$ calcined at $500{ }^{\circ} \mathrm{C}$, the $\mathrm{CO}_{2}$ peak at $425^{\circ} \mathrm{C}$ is attributed to the reduction of the lattice oxygen and active oxygen on the support surface. Compared to the $\mathrm{PdAg} / \mathrm{Z}$ catalysts, the reduction temperature decreased because the SMI was able to promote the migration of lattice oxygen and facilitate the oxidation of $\mathrm{CO}$ [32]. Changing of the calcination temperature enabled the alteration of the structure of $\mathrm{Pd}-\mathrm{O}-\mathrm{Zr}$, and then changed the degree of manipulation of $\mathrm{PdAg}$ by $\mathrm{ZrO}_{2}$. From Figure 8, it is found that the $\alpha$ peaks $\left(207-232{ }^{\circ} \mathrm{C}\right)$ become more and more sharp as the calcination temperature increased, proving that as the calcination temperature increased, the degree of SMI gradually strengthened, enabling the active oxygen species to easily migrate on the catalyst surface. However, as the calcination temperature $\left(<850^{\circ} \mathrm{C}\right)$ cannot produce moderate SMI, the $\mathrm{PdAg} / \mathrm{Z}-850$ would have better catalytic performance than $\mathrm{PdAg} / \mathrm{Z}-600$ and $\mathrm{PdAg} / \mathrm{Z}-700$. The $\beta$ peaks at $390-430{ }^{\circ} \mathrm{C}$ are the reduction of lattice oxygen and active oxygen 
at the interface between $\mathrm{Pd}$ and $\mathrm{ZrO}_{2}$. This is the main active component of the $\mathrm{PdAg} / \mathrm{Z}$ catalyst. From the CO-TPR curves, we find that the reduction temperature of the lattice oxygen and the oxygen species at the support-metal interface is consistent with the change trend of the catalyst performance, which indicates that the reducibility of active oxygen at the support-metal interface and the mobility of lattice oxygen would directly affect the catalytic performance. This is consistent with the $\mathrm{H}_{2}-\mathrm{TPR}$ results.

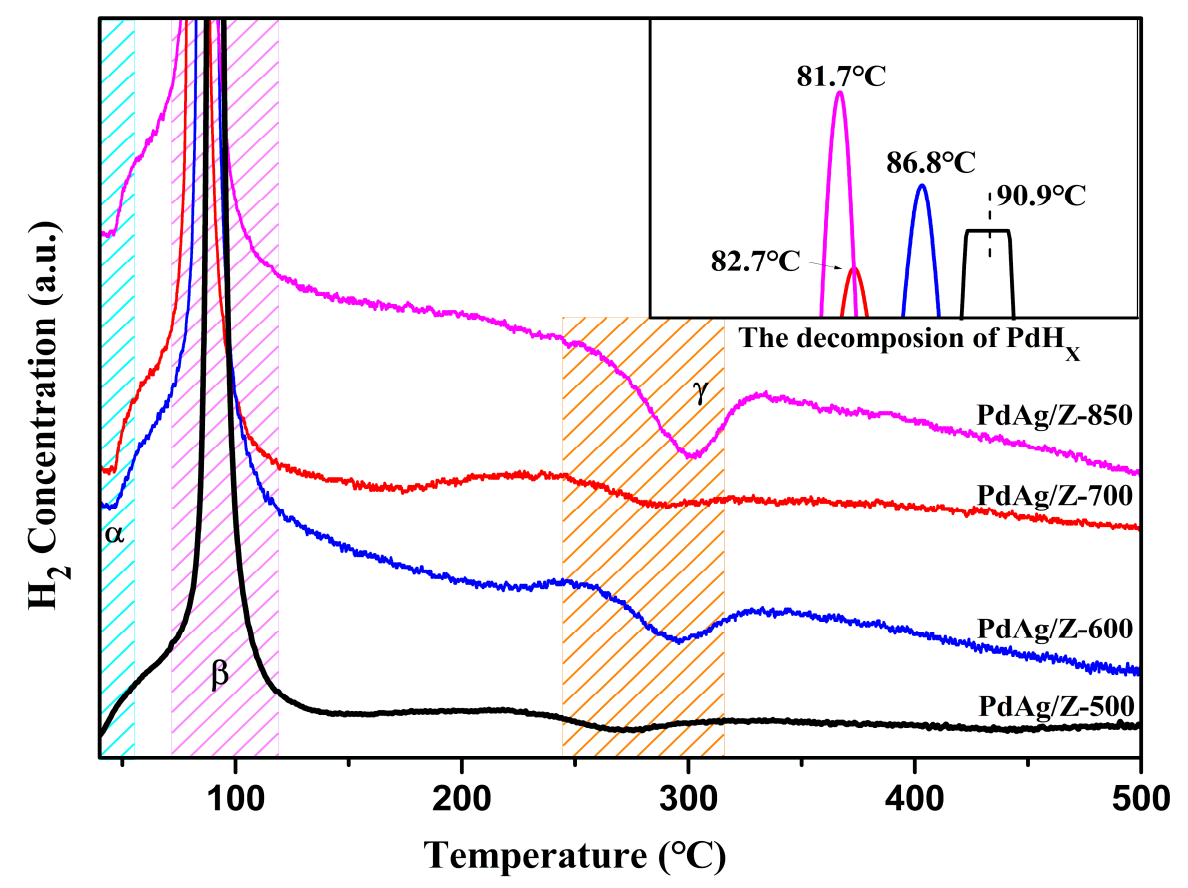

Figure 7. $\mathrm{H}_{2}$ temperature programmed reduction $\left(\mathrm{H}_{2}-\mathrm{TPR}\right)$ profiles of $\mathrm{PdAg} / \mathrm{Z}$ catalysts calcined at different temperatures.

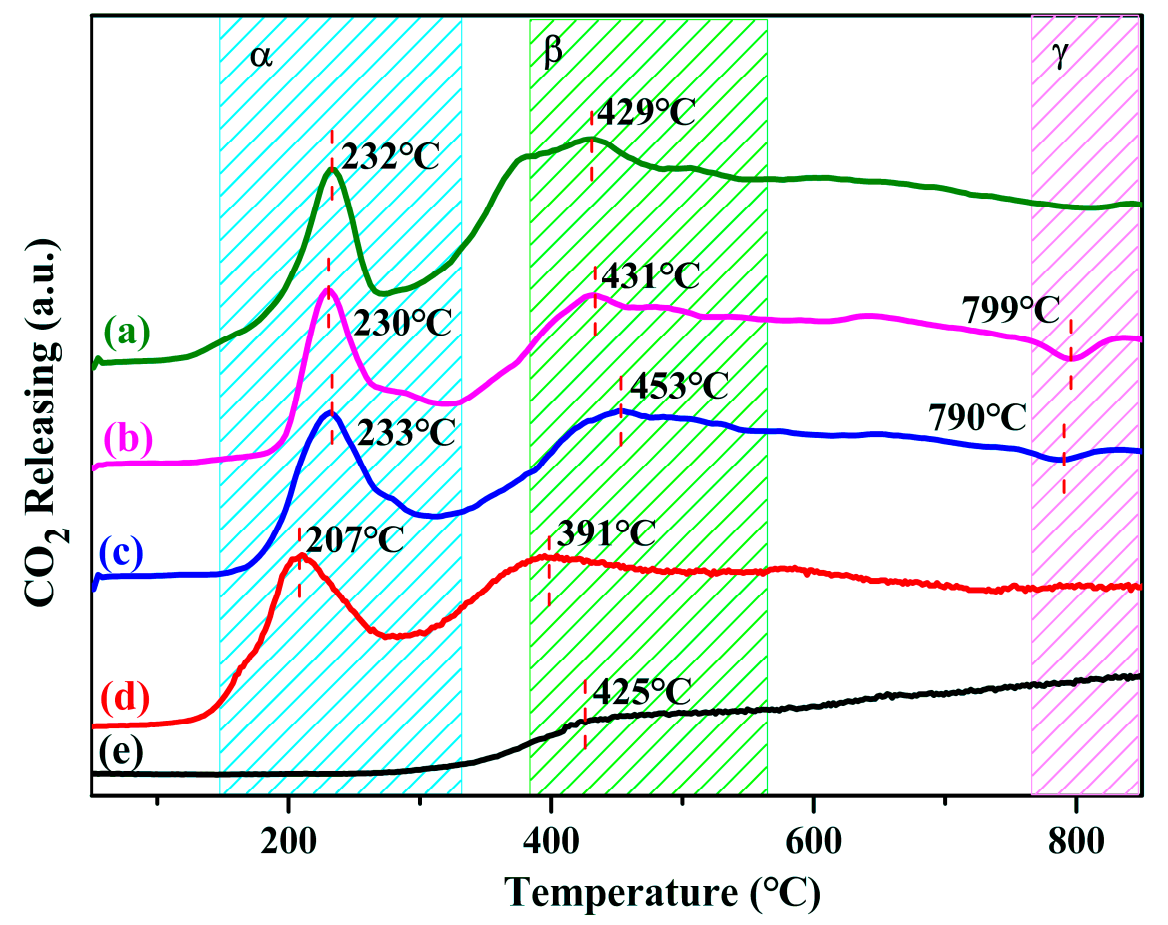

Figure 8. CO temperature programmed reduction (CO-TPR) profiles of PdAg/Z catalysts calcined at different temperatures. (a) PdAg/Z-850; (b) PdAg/Z-700; (c) PdAg/Z-600; (d) PdAg/Z-500, and (e) support. 


\subsubsection{X-ray Photoelectron Spectroscopy Analysis}

Figure 9 shows the XPS curves of $\mathrm{PdAg} / \mathrm{Z}$ alloy catalysts calcined at different temperatures. The figure displays that the binding energy of $\mathrm{Pd}^{2+}$ remains basically unchanged at $336.5 \mathrm{eV}$ with the increase of calcining temperature [33,34], but the binding energy of metallic Pd shifts from 335.0 to $335.3 \mathrm{eV}$ [35]. It means that the content of metallic Pd decreased. However, combined with Table 1 , it can be found that the binding energy of $\mathrm{Ag}$ reduced $0.2 \mathrm{eV}$ when the calcination temperature was at $850^{\circ} \mathrm{C}$, which shows that the content of Ag increased. Therefore, the addition of Ag could maintain the PdO-Pd mixture active phase containing much more $\mathrm{Pd}^{2+}$ at a high temperature and thus the catalytic activity is improved. The statistical catalyst surface atomic ratio of each element is listed in Table 1 . With the increase of calcination temperature, the $\mathrm{Pd} / \mathrm{Zr}$ ratio remains the same. This shows that the PdAg/Z-850 catalysts could still maintain good dispersion; thus, Ag can improve catalyst high temperature sintering resistance. It can be seen from the ratio of $\mathrm{Pd}^{2+} / \mathrm{Pd}^{0}$ that as the calcination temperature increased, the change trend of the ratio of $\mathrm{Pd}^{2+} / \mathrm{Pd}^{0}$ was consistent with that of the catalytic activity. It is indicated that the active phase with a higher $\mathrm{Pd}^{2+} / \mathrm{Pd}^{0}$ ratio will have a better catalytic activity for methane combustion.

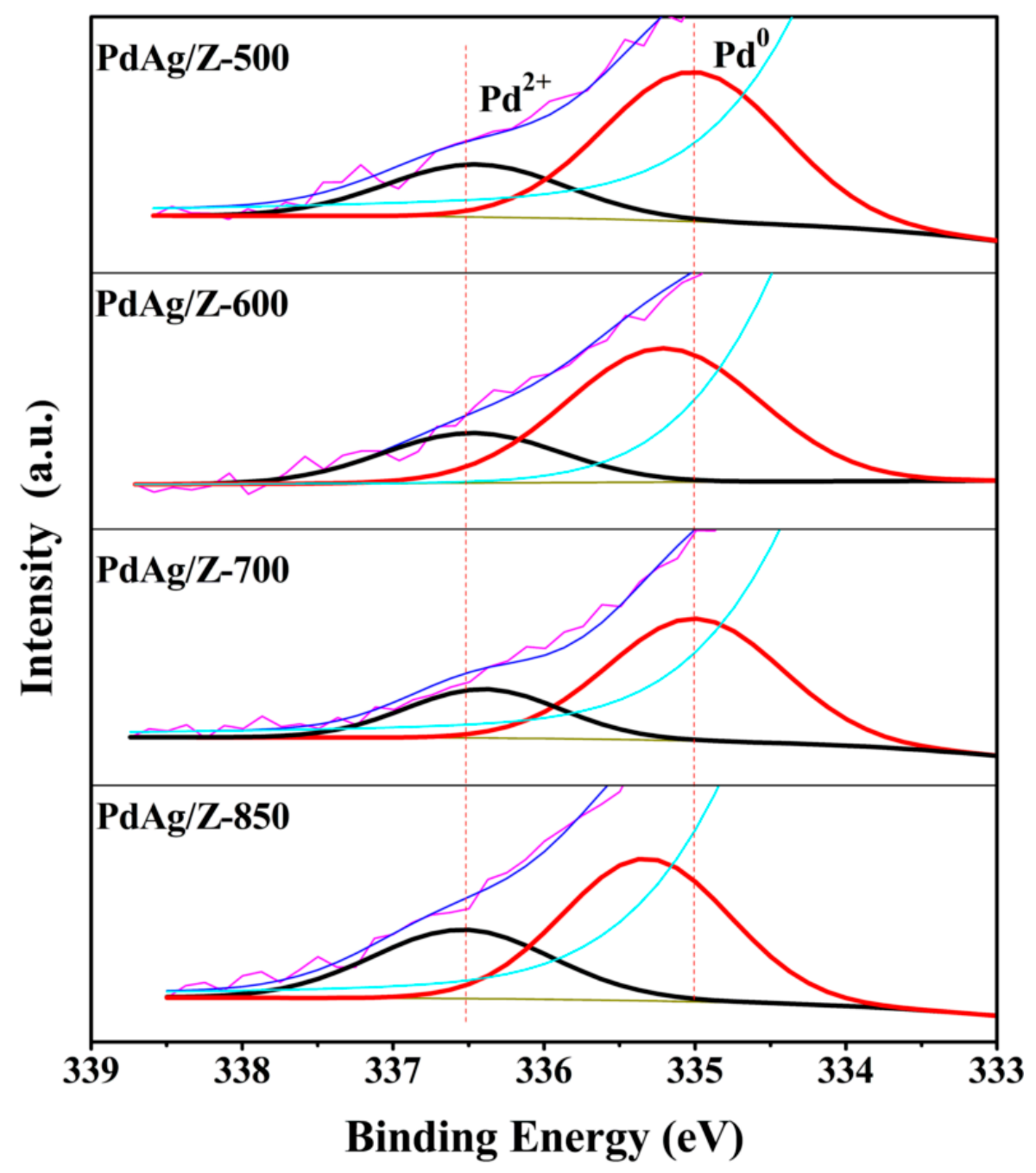

Figure 9. XPS curves of $\mathrm{PdAg} / \mathrm{Z}$ alloy catalysts calcined at different temperatures. 
Table 1. Chemical state analysis from XPS characterization.

\begin{tabular}{|c|c|c|c|c|c|c|c|c|}
\hline \multirow{3}{*}{$\begin{array}{c}\text { Calcined } \\
\text { Temperat } \\
/{ }^{\circ} \mathrm{C}\end{array}$} & \multicolumn{5}{|c|}{ Peaks of Binding Energy / eV } & \multicolumn{3}{|c|}{ Atomic Ratio } \\
\hline & urePd & $d_{5 / 2}$ & Ag & $d_{5 / 2}$ & \multirow{2}{*}{ O 1s } & \multirow{2}{*}{$\mathrm{Pd} / \mathrm{Zr}$} & \multirow{2}{*}{$\mathrm{Pd}^{2+} / \mathrm{Pd}$} & \multirow{2}{*}{$\mathrm{Ag} / \mathrm{Ag}^{+}$} \\
\hline & Pd & $\mathrm{Pd}^{2+}$ & $\mathrm{Ag}$ & $\mathrm{Ag}^{+}$ & & & & \\
\hline 500 & 335.0 & 336.5 & 367.4 & 368.2 & 529.8 & 0.08 & 0.35 & 0.53 \\
\hline 600 & 335.2 & 336.5 & 367.4 & 368.0 & 529.8 & 0.12 & 0.34 & 0.71 \\
\hline 700 & 335.1 & 336.4 & 367.4 & 368.2 & 529.9 & 0.09 & 0.35 & 2.67 \\
\hline 850 & 335.3 & 336.5 & 367.2 & 368.4 & 529.9 & 0.08 & 0.53 & 5.10 \\
\hline
\end{tabular}

\section{Materials and Methods}

\subsection{Catalysts Preparation}

A reference catalyst of $1 \mathrm{wt} \% \mathrm{PdAg} / \mathrm{ZrO}_{2}$ was prepared by the incipient wetness impregnation method. The Pd:Ag molar ratios of the finished alloy catalyst was 10:1. Pd( $\left.\mathrm{NH}_{3}\right)_{4}\left(\mathrm{NO}_{3}\right)_{2}$ (Strem Chemicals, Newburyport, MA, USA, 5.0 wt. \% Pd) and $\mathrm{AgNO}_{3}$ (XiLong Chemicals, Shantou, Guangdong, China, 99.8 \%) were dissolved in the deionized water, then $\mathrm{ZrO}_{2}$ (J\&K Chemicals, Beijing, China, $99.5 \%$ ) powder was added into the mixture solution under slow stirring. After impregnation, the sample was dried at $120^{\circ} \mathrm{C}$ overnight. In order to explore the effect of calcination temperature on SMI, the catalysts were calcined at different temperature after 7 days' ripening. A series of $\mathrm{PdAg} / \mathrm{Z}$ catalysts calcined at 500 , 600,700 , and $850^{\circ} \mathrm{C}$ were named $\mathrm{PdAg} / \mathrm{Z}-500, \mathrm{PdAg} / \mathrm{Z}-600, \mathrm{PdAg} / \mathrm{Z}-700$, and $\mathrm{PdAg} / \mathrm{Z}-850$ respectively.

The procedure of seven-day ripening is introduced to settle the unsteady mixed metal components, which were freshly deposited on the zirconia support. As shown in the supporting information, the sample without ripening usually presents a more oxidative state after calcination. The process of ripening can limit the SMI to the interface between the metal and the support, on which further interaction is suppressed by particle growing. Given that the calcination intervals usually last for a few days, the conformance of samples would be guaranteed by adequate ripening.

\subsection{Catalytic Activity for Methane Oxidation}

Catalytic methane combustion was performed in a quartz fix-bed flow reactor at atmospheric pressure. The gas flow was controlled by a mass flow controller (Sevenstar D07-19B MFC, Beijing, China,) to regulate the composition of gas mixture. The reaction temperature was measured by a K-type thermocouple placed at the bottom of the catalyst bed in order to measure the exit temperature close to the reaction zone. Using $50 \mathrm{mg}, 40-60$ mesh $(0.25-0.40 \mathrm{~mm}$ in diameter) fresh sample was loaded in the fix-bed quartz reactor $\left(\phi_{\text {out }}=6 \mathrm{~mm}, \phi_{\text {in }}=4 \mathrm{~mm}\right.$ ) with heating rate of $10^{\circ} \mathrm{C} \mathrm{min}^{-1}$ under a flow rate of $40 \mathrm{~mL} \mathrm{~min}^{-1}$ of reacting feedstock $\left(2 \mathrm{vol} \% \mathrm{CH}_{4} / \mathrm{Ar}\right.$ and $4 \mathrm{vol} \% \mathrm{O}_{2} / \mathrm{Ar}$, space velocity $\left.72,000 \mathrm{~h}^{-1}\right)$ under stoichiometric conditions $\left(\mathrm{O}_{2} / \mathrm{CH}_{4}=2\right)$ of total oxidation. The activity measurement started from $250{ }^{\circ} \mathrm{C}$ and was performed at every $50^{\circ} \mathrm{C}$ of temperature elevation. When the temperature reached the programmed condition, it was maintained for $20 \mathrm{~min}$ under the reaction gas atmosphere. The effluents from the reactor were analyzed by on-line gas chromatograph (Haixin GC 950, Shanghai, China,) equipped with a TCD detector. Prior to TCD detection, the effluent mixture was separated by a packed column of 5A molecular sieve.

\subsection{Catalyst Characterization}

X-ray diffraction analysis of the catalysts were carried out using a Rigaku Ultima IV X-ray powder diffraction spectrometer (Japan), operated at $35 \mathrm{kV}$, and $15 \mathrm{~mA}$ employing $\mathrm{Cu}$ Ka radiation. Specifically, step width was $0.02^{\circ}$ and scan range was measured from 20 to $80^{\circ}$ with scanning speed of $10^{\circ}$ per min.

High-resolution transmission electron microscopy studies were performed on Tecnai 30 (Holland). Samples were prepared by dry dispersing the catalyst powder onto a holey carbon film supported by a 300 mesh copper grid. The appearance and the chemical dispersion of $\mathrm{Pd}, \mathrm{Ag}$, and $\mathrm{ZrO}_{2}$ were 
recorded on transmission electron microscopy images. The fringe statistics of alloy particles and the support were calculated by Digital Micrograph software (USA).

$\mathrm{H}_{2}$ temperature programmed reduction $\left(\mathrm{H}_{2}-\mathrm{TPR}\right)$ experiments were carried out at Shimadzu GC 8A chromatography and the $\mathrm{H}_{2}$ signal was monitored by TCD. About $50 \mathrm{mg}$ catalyst particles (dp $0.250 \sim 0.425 \mathrm{~mm}$ ) were placed in a quartz micro-reactor. Prior to the experiment, the sample was pretreated in the argon $(99.99 \%)$ flow $\left(30 \mathrm{~mL} \mathrm{~min}^{-1}\right)$ at $300{ }^{\circ} \mathrm{C}$ for $1 \mathrm{~h}$, followed by a decrease to $40{ }^{\circ} \mathrm{C}$. When the temperature cooled to $40{ }^{\circ} \mathrm{C}$, the flow of $5 \% \mathrm{H}_{2} / \mathrm{Ar}$ was switched into the reactor. Finally, the temperature increased from $40^{\circ} \mathrm{C}$ to $800{ }^{\circ} \mathrm{C}$ at a heating rate of $10^{\circ} \mathrm{C} \mathrm{min}^{-1}$. During the period of temperature-rise, the concentration of $\mathrm{H}_{2}$ in the effluent gas was continuously recorded by TCD.

$\mathrm{CO}$ temperature programmed reduction (CO-TPR) characterization was monitored by Hiden QIC-20 Mass Spectrometer (UK). A continuous flow of air passed over the $50 \mathrm{mg}$ fresh sample. The temperature increased from room temperature to $300{ }^{\circ} \mathrm{C}$ at a rate of $10{ }^{\circ} \mathrm{C} \mathrm{min}-1$ and was maintained for $60 \mathrm{~min}$, followed by a decrease to $40^{\circ} \mathrm{C}$. When the temperature cooled to $40^{\circ} \mathrm{C}$, the flow of $2 \% \mathrm{CO} / \mathrm{He}$ was switched into the system. Finally, the temperature increased from 40 to $900{ }^{\circ} \mathrm{C}$ with the heating ramp $10^{\circ} \mathrm{C} \mathrm{min}^{-1}$. The signal of $\mathrm{m} / \mathrm{z}=2,16,18,28$, and 44 were recorded simultaneously.

$\mathrm{O}_{2}$ temperature programmed desorption $\left(\mathrm{O}_{2}-\mathrm{TPD}\right)$ experiments were performed using a $50 \mathrm{mg}$ sample placed in a quartz reactor. The outlet of the reactor was connected with a Hiden QIC-20 quadrupole mass spectrometer. Before the $\mathrm{O}_{2}$-TPD testing, the sample was oxidized in $1 \% \mathrm{O}_{2} / \mathrm{He}$ flow $\left(30 \mathrm{~mL} \mathrm{~min}^{-1}\right)$. The sample bed was heated at a rate of $10^{\circ} \mathrm{C} \mathrm{min}^{-1}$ from room temperature up to $500{ }^{\circ} \mathrm{C}$ and hold at this temperature for $30 \mathrm{~min}$, then cooled to $30^{\circ} \mathrm{C}$ at a rate of $5{ }^{\circ} \mathrm{C} \mathrm{min}-1$. When the temperature was cooled to $30^{\circ} \mathrm{C}, \mathrm{He}(99.99 \%)$ was switched into the reactor. Finally, the temperature increased from 30 to $900{ }^{\circ} \mathrm{C}$ with the heating ramp $10{ }^{\circ} \mathrm{C} \mathrm{min}^{-1}$ under $\mathrm{He}(99.99 \%)$ atmosphere and signals of $m / z=16,32,18,28$, and 44 in outlet gas were recorded.

X-ray photoelectron spectroscopy (XPS) analysis was performed on a PHI 5000C ESCA System instrument (Japan). Spectra were recorded by using monochromatized $\mathrm{Al} \mathrm{K} \alpha$ radiation $(1486.6 \mathrm{~V})$, with an X-ray power of $250 \mathrm{~W}$. The spectrometer was operated in the analysis chamber: vacuum was $1.0 \times 10^{8}$ Torr, working voltage was $14.0 \mathrm{kV}$, and signal accumulation of 100 cycles were performed. The $\mathrm{C} 1 \mathrm{~s}$ peak $(284.6 \mathrm{eV})$ was used for the calibration of binding energy values. $\mathrm{The}^{\mathrm{Pd}}{ }^{2+} / \mathrm{Pd}^{0}$ was calculated according to $\mathrm{D}=\mathrm{A}\left(\mathrm{Pd}^{2+}\right) / \mathrm{A}\left(\mathrm{Pd}^{0}\right)$, where $\mathrm{A}\left(\mathrm{Pd}^{2+}\right)$ is the peak area of $\mathrm{Pd}^{2+}$ and $\mathrm{A}\left(\mathrm{Pd}^{0}\right)$ is that of $\mathrm{Pd}^{0}$. XPS data analysis was performed with the XPSPEAK41 software (USA).

\section{Conclusions}

In this paper, a series of $\mathrm{PdAg} / \mathrm{Z}$ catalysts were investigated. We find that the presence of $\mathrm{Ag}$ inhibits the sintering of $\mathrm{Pd}$ during calcination at high temperature. The HRTEM observations also reveal a specific microdomain structure between the metal and the support. This may be the evidence of SMI. In addition, it is found that the degree of SMI can be adjusted by changing the calcination temperature. The analysis of catalytic activity for methane oxidation illustrates that PdAg/Z-500 shows the highest methane conversion. As the temperature increases, the sintering of active phase occurs, which results in lower catalytic activity. However, further increase of the calcination temperature enhances the beneficial SMI. It facilitates the active phase that meets the demand of structural sensitivity for methane combustion. The PdAg/Z-850 catalyst exhibited higher activity $\left(\mathrm{T}_{90}\right.$ at $\left.550{ }^{\circ} \mathrm{C}\right)$ in methane catalytic combustion. On combining the characterization results of $\mathrm{O}_{2}$-TPD and TPR, the conclusion can be drawn that the degree of SMI differs with changing calcination temperature, which leads to the formation of various structures of the PdO-Pd active phase. Through XPS analysis, Ag can maintain proper $\mathrm{Pd}^{2+} / \mathrm{Pd}^{0}$; thus, the catalysts can have suitable active phase composition. Therefore, controllability of the catalytic performance could be brought about by adjusting calcining temperature.

Supplementary Materials: The following are available online at http://www.mdpi.com/2073-4344/10/8/863/s1, Figure S1: XPS curve of PdAg/Z alloy catalyst without ripening treatment.

Author Contributions: Conceptualization, M.C. and L.Y.; Data curation, M.C., F.C. and L.X.; Funding acquisition, X.Y. and W.F.; Investigation, M.C., F.C., X.C. and L.X.; Methodology, M.C. and X.C.; Project administration, 
X.Y.; Software, F.C.; Supervision, L.Y. and W.F.; Writing—original draft, M.C.; Writing—review \& editing, L.Y. All authors have read and agreed to the published version of the manuscript.

Funding: The research was funded by National Natural Science Foundation of China (Funding Number: 21373171).

Conflicts of Interest: The authors declare no conflict of interest.

\section{References}

1. Choudhary, T.V.; Banerjee, S.; Choudhary, V.R. Catalysts for combustion of methane and lower alkanes. Appl. Catal. A Gen. 2002, 234,1-23. [CrossRef]

2. Dai, Y.; Pavan Kumar, V.; Zhu, C.; MacLachlan, M.J.; Smith, K.J.; Wolf, M.O. Mesoporous Silica-Supported Nanostructured $\mathrm{PdO} / \mathrm{CeO}_{2}$ Catalysts for Low-Temperature Methane Oxidation. ACS Appl. Mater. Interfaces 2018, 10, 477-487. [CrossRef] [PubMed]

3. Geng, H.; Zhang, L.; Yang, Z.; Yan, Y.; Ran, J. Effect of Pd/Pt ratio on the reactivity of methane catalytic combustion in bimetallic Pd-Pt catalyst. Int. J. Hydrogen Energy 2018, 43, 11069-11078. [CrossRef]

4. Gremminger, A.T.; Pereira de Carvalho, H.W.; Popescu, R.; Grunwaldt, J.-D.; Deutschmann, O. Influence of gas composition on activity and durability of bimetallic $\mathrm{Pd}-\mathrm{Pt} / \mathrm{Al}_{2} \mathrm{O}_{3}$ catalysts for total oxidation of methane. Catal. Today 2015, 258, 470-480. [CrossRef]

5. Goud, S.K.; Whittenberger, W.A.; Chattopadhyay, S.; Abraham, M.A. Steam reforming of n-hexadecane using a $\mathrm{Pd} / \mathrm{ZrO}_{2}$ catalyst: Kinetics of catalyst deactivation. Int. J. Hydrogen Energy 2007, 32, 2868-2874. [CrossRef]

6. Christian, A.; Müller, M.M.; René, A. Koeppel, and Alfons Baiker, Combustion of Methane over Palladium/Zirconia Derived from a Glassy Pd-Zr Alloy: Effect of Pd Particle Size on Catalytic Behavior. J. Catal. 1997, 166, 36-43.

7. Carstens, J.N.; Su, S.C.; Bell, A.T. Factors affecting the catalytic activity of $\mathrm{Pd} / \mathrm{ZrO}_{2}$ for the combustion of methane. J. Catal. 1998, 176, 136-142. [CrossRef]

8. Epling, W.S.; Hoflund, G.B. Catalytic Oxidation of Methane over $\mathrm{ZrO}_{2}$-Supported Pd Catalysts. J. Catal. 1999, 182, 5-12. [CrossRef]

9. Escandón, L.S.; Niño, D.; Díaz, E.; Ordóñez, S.; Díez, F.V. Effect of hydrothermal ageing on the performance of Ce-promoted $\mathrm{PdO} / \mathrm{ZrO}_{2}$ for methane combustion. Catal. Commun. 2008, 9, 2291-2296. [CrossRef]

10. Narui, K.; Yata, H.; Furuta, K.; Nishida, A.; Kohtoku, Y.; Matsuzaki, T. Effects of addition of Pt to PdO/Al ${ }_{2} \mathrm{O}_{3}$ catalyst on catalytic activity for methane combustion and TEM observations of supported particles. Appl. Catal. A Gen. 1999, 179, 165-173. [CrossRef]

11. Persson, K.; Ersson, A.; Jansson, K.; Iverlund, N.; Järås, S. Influence of co-metals on bimetallic palladium catalysts for methane combustion. J. Catal. 2005, 231, 139-150. [CrossRef]

12. Alegre, V.V.; da Silva, M.A.P.; Schmal, M. Catalytic combustion of methane over palladium alumina modified by niobia. Catal. Commun. 2006, 7, 314-322. [CrossRef]

13. He, Y.; Liu, Y.; Yang, P.; Du, Y.; Feng, J.; Cao, X.; Yang, J.; Li, D. Fabrication of a PdAg mesocrystal catalyst for the partial hydrogenation of acetylene. J. Catal. 2015, 330, 61-70. [CrossRef]

14. Sadokhina, N.; Smedler, G.; Nylén, U.; Olofsson, M.; Olsson, L. Deceleration of $\mathrm{SO}_{2}$ poisoning on $\mathrm{PtPd} / \mathrm{Al}_{2} \mathrm{O}_{3}$ catalyst during complete methane oxidation. Appl. Catal. B Environ. 2018, 236, 384-395. [CrossRef]

15. Persson, K.; Ersson, A.; Jansson, K.; Fierro, J.; Jaras, S. Influence of molar ratio on Pd-Pt catalysts for methane combustion. J. Catal. 2006, 243, 14-24. [CrossRef]

16. Qi, W.; Ran, J.; Zhang, Z.; Niu, J.; Zhang, P.; Fu, L.; Hu, B.; Li, Q. Methane combustion reactivity during the metal $\rightarrow$ metallic oxide transformation of Pd-Pt catalysts: Effect of oxygen pressure. Appl. Surf. Sci. 2018, 435, 776-785. [CrossRef]

17. Gremminger, A.; Lott, P.; Merts, M.; Casapu, M.; Grunwaldt, J.-D.; Deutschmann, O. Sulfur poisoning and regeneration of bimetallic Pd-Pt methane oxidation catalysts. Appl. Catal. B Environ. 2017, 218, 833-843. [CrossRef]

18. Shen, S.Y.; Zhao, T.S.; Xu, J.B.; Li, Y.S. Synthesis of PdNi catalysts for the oxidation of ethanol in alkaline direct ethanol fuel cells. J. Power Sources 2010, 195, 1001-1006. [CrossRef]

19. Safavi, A.; Momeni, S.; Tohidi, M. Silver-Palladium Nanoalloys Modified Carbon Ionic Liquid Electrode with Enhanced Electrocatalytic Activity Towards Formaldehyde Oxidation. Electroanalysis 2012, 24, 1981-1988. [CrossRef] 
20. Resende, K.A.; Teles, C.A.; Jacobs, G.; Davis, B.H.; Cronauer, D.C.; Kropf, A.J.; Marshall, C.L.; Hori, C.E.; Noronha, F.B. Hydrodeoxygenation of Phenol over Zirconia Supported Pd Bimetallic Catalysts. The Effect of Second Metal on Catalyst Performance. Appl. Catal. B Environ. 2018, 232, 213-231. [CrossRef]

21. Tauster, S.J.; Fung, S.C. Strong metal-support interactions: Occurrence among the binary oxides of groups IIA-VB. J. Catal. 1978, 55, 29-35. [CrossRef]

22. Murata, K.; Kosuge, D.; Ohyama, J.; Mahara, Y.; Yamamoto, Y.; Arai, S.; Satsuma, A. Exploiting Metal-Support Interactions to Tune the Redox Properties of Supported Pd Catalysts for Methane Combustion. ACS Catal. 2019, 10, 1381-1387. [CrossRef]

23. O'Shea, V.A.; Galvan, M.C.; Prats, A.E.; Campos-Martin, J.M.; Fierro, J.L. Direct evidence of the SMSI decoration effect: The case of $\mathrm{Co} / \mathrm{TiO}_{2}$ catalyst. Chem. Comm. 2011, 47, 7131-7133.

24. Cao, Y.; Ran, R.; Wu, X.; Zhao, B.; Wan, J.; Weng, D. Comparative study of ageing condition effects on $\mathrm{Pd} / \mathrm{Ce}_{0.5} \mathrm{Zr}_{0.5} \mathrm{O}_{2}$ and $\mathrm{Pd} / \mathrm{Al}_{2} \mathrm{O}_{3}$ catalysts: Catalytic activity, palladium nanoparticle structure and Pd-support interaction. Appl. Catal. A Gen. 2013, 457, 52-61. [CrossRef]

25. Okumura, K.; Kobayashi, T.; Tanaka, H.; Niwa, M. Toluene combustion over palladium supported on various metal oxide supports. Appl. Catal. B Environ. 2003, 44, 325-331. [CrossRef]

26. Huang, F.; Chen, J.; Hu, W.; Li, G.; Wu, Y.; Yuan, S.; Zhong, L.; Chen, Y. Pd or PdO: Catalytic active site of methane oxidation operated close to stoichiometric air-to-fuel for natural gas vehicles. Appl. Catal. B Environ. 2017, 219, 73-81. [CrossRef]

27. Nilsson, J.; Carlsson, P.-A.; Martin, N.M.; Velin, P.; Meira, D.M.; Grönbeck, H.; Skoglundh, M. Oxygen step-response experiments for methane oxidation over $\mathrm{Pd} / \mathrm{Al}_{2} \mathrm{O}_{3}$ : An in situ XAFS study. Catal. Commun. 2018, 109, 24-27. [CrossRef]

28. Jiang, Y.; Buchel, R.; Huang, J.; Krumeich, F.; Pratsinis, S.E.; Baiker, A. Efficient solvent-free hydrogenation of ketones over flame-prepared bimetallic Pt-Pd/ZrO(2) catalysts. ChemSusChem 2012, 5, 1190-1194. [CrossRef]

29. Yamazaki, K.; Kayama, T.; Dong, F.; Shinjoh, H. A mechanistic study on soot oxidation over $\mathrm{CeO}_{2}-\mathrm{Ag}$ catalyst with 'rice-ball' morphology. J. Catal. 2011, 282, 289-298. [CrossRef]

30. Seshu Babu, N.; Lingaiah, N.; Sai Prasad, P.S. Characterization and reactivity of $\mathrm{Al}_{2} \mathrm{O}_{3}$ supported Pd-Ni bimetallic catalysts for hydrodechlorination of chlorobenzene. Appl. Catal. B Environ. 2012, 111-112, 309-316. [CrossRef]

31. Tidahy, H.L.; Hosseni, M.; Siffert, S.; Cousin, R.; Lamonier, J.F.; Aboukaïs, A.; Su, B.L.; Giraudon, J.M.; Leclercq, G. Nanostructured macro-mesoporous zirconia impregnated by noble metal for catalytic total oxidation of toluene. Catal. Today 2008, 137, 335-339. [CrossRef]

32. Yang, L.; Shan, S.; Loukrakpam, R.; Petkov, V.; Ren, Y.; Wanjala, B.N.; Engelhard, M.H.; Luo, J.; Yin, J.; Chen, Y.; et al. Role of support-nanoalloy interactions in the atomic-scale structural and chemical ordering for tuning catalytic sites. J. Am. Chem. Soc. 2012, 134, 15048-15060. [CrossRef]

33. Resende, K.A.; Hori, C.E.; Noronha, F.B.; Shi, H.; Gutierrez, O.Y.; Camaioni, D.M.; Lercher, J.A. Aqueous phase hydrogenation of phenol catalyzed by $\mathrm{Pd}$ and PdAg on $\mathrm{ZrO}_{2}$. Appl. Catal. A Gen. 2017, 548, 128-135. [CrossRef]

34. Feng, Y.-S.; Hao, J.; Liu, W.-W.; Yao, Y.-J.; Cheng, Y.; Xu, H.-J. Characterization and reactivity of $\gamma-\mathrm{Al}_{2} \mathrm{O}_{3}$ supported $\mathrm{Pd}-\mathrm{Ni}$ bimetallic nanocatalysts for selective hydrogenation of cyclopentadiene. Chin. Chem. Lett. 2015, 26, 709-713. [CrossRef]

35. Park, J.-H.; Cho, J.H.; Kim, Y.J.; Kim, E.S.; Han, H.S.; Shin, C.-H. Hydrothermal stability of Pd/ZrO 2 catalysts for high temperature methane combustion. Appl. Catal. B Environ. 2014, 160-161, 135-143. [CrossRef]

(C) 2020 by the authors. Licensee MDPI, Basel, Switzerland. This article is an open access article distributed under the terms and conditions of the Creative Commons Attribution (CC BY) license (http://creativecommons.org/licenses/by/4.0/). 